\title{
New and remarkable desmids (Zygnematophyceae, Streptophyta) from Europe: taxonomical notes based on LM and SEM observations
}

\author{
Jan ŠŤASTNÝ ${ }^{1} \&$ Frans A.C. KouwETS ${ }^{2}$ \\ ${ }^{1}$ Department of Botany, Charles University of Prague, Benátská 2, CZ-128 01 Prague, Czech Republic; e-mail: \\ stastny.jan@centrum.cz \\ ${ }^{2}$ RWS Centre for Water Management, Department of Hydrobiology, Zuiderwagenplein 2, 8224 AD Lelystad, The \\ Netherlands; e-mail:frans.kouwets@rws.nl
}

\begin{abstract}
In the present paper, the morphology and taxonomy of seven desmid taxa collected in various European habitats is discussed, mainly on the basis of scanning electron microscopic observations of cell wall sculpturing. Four taxa (Actinotaenium riethii, Closterium pseudocostatum, Cosmarium discrepans and C. hostensiense) are newly described and the name of one taxon (Cosmarium lenzenwegeri) is recombined. In addition, the morphology of Cosmarium cataractarum and C. cinctutum is described in greater detail, confirming their status as independent species.
\end{abstract}

Key words: Actinotaenium, cell wall sculpture, Closterium, Cosmarium, Desmidiales, ephemeral habitats, morphology, new species, scanning electron microscopy, taxonomy

\section{Introduction}

Traditional desmid taxonomy is mainly based on differences in cell morphology and wall sculpturing (e.g. Brook 1981). However, since about the last two decades, molecular research has increasingly, and sometimes controversially been turning desmid taxonomy upside down, especially at the level of genus and higher (e.g. McCourT et al. 2000; Gontcharov et al. 2003; NeuStuPa \& ŠKaloud 2007; Gontcharov 2008; Hall et al. 2008; Gontcharov \& MelKonian 2005, 2008, 2010). Only very recently molecular methods have also been used in the evaluation of taxonomic concepts of traditional, morphology-based taxa at the level of species and variety, resulting in remarkable taxonomic changes (Neustupa et al. 2010, 2011; NemJovÁ et al. 2011).

However, assuming a careful and critical application, the traditional analysis of cell morphology may still provide a lot of important and useful taxonomical data. Some general morphological characters are prominent, well defined and clearly visible under the light microscope, and may even distinguish between genera. Other characters are very variable, or inconspicuous and less well visible, such as cell wall sculpturing and pore patterns. The morphological variability ranging from apparently smooth to profusely sculptured makes the desmid cell wall perfectly suited for studies using scanning electron microscopy (SEM; see, e.g., Couté \& Tell 1981; Coesel 1984). Therefore, in addition to the regular line drawings after light microscopical observations in the present study we also used a scanning electron microscope to clearly illustrate the discriminative morphological characters of the individual taxa.

Extensive sampling of desmids by the first author in the Czech Republic (ŠŤASTNÝ 2010) and also in several other European countries revealed a number of remarkable forms that apparently needed a more detailed study to clear up their taxonomy. In the present paper we discuss seven of them.

\section{Materials and Methods}

The samples were microscopically analyzed using an Olympus BX51 light microscope, and line drawings were made using a drawing tube.

For scanning electron microscopy (SEM) acetone-washed glass coverslips (10 or $12 \mathrm{~mm}$ in diameter) were placed on a heating block, and coated three times with a poly-L-lysine solution (Sigma, 1:10 in distilled water) to ensure better adhesion of the desmid cells. After cooling, a drop of the formaldehyde-fixed 
material was placed on the glass and when almost dry, it was transferred into $30 \%$ acetone and dehydrated by an acetone series $(30,50,70,90,95,99 \%$ and $2 \mathrm{x}$ in $100 \%, 10$ minutes each ). Finally, the cells were dried to critical-point with liquid $\mathrm{CO}_{2}$, subsequently sputter coated with gold and examined using a Phenom Desktop or JEOL 6380 LV scanning electron microscope.

Environmentalvariables ( $\mathrm{pH}$, conductivity) were measured either with a Combo HI 98129 (HANNA, Germany) portable instrument or with a WTW 330 pH-meter and WTW LF 315 conductometer (WTW, Germany). The list of all sampling sites is given in Table 1.

\section{Results and Discussion}

\section{Closterium pseudocostatum ŠŤASTNÝ et KouwETS} sp. nov. (Figs 1-9, 22-27)

Descriptio: cellulae moderate curvatae, media parte rectis, cingulis veris, ad utrumque polum sensim attenuatis, apicibus late tholiformibus, membrana ochroa costata striis circiter 2-6/10 $\mu \mathrm{m}$. Cellularum

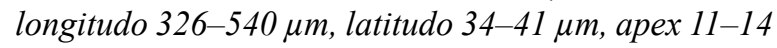
$\mu \mathrm{m}$, long./lat. circiter 9-15.

Description: cells only slightly curved, in the midregion straight and cylindric, towards the ends gradually attenuated, with more or less conical, cowl- or dome-shaped apices. Cell wall with true girdle bands, brownish, more or less coarsely costate $(2-6$ str. $/ 10 \mu \mathrm{m})$.

Dimensions: length $326-540 \mu \mathrm{m}$, width $34-41$ $\mu \mathrm{m}$, length/width ratio approximately 9-15.

Type locality: site 2 (see Table 1), leg. J. Št’astný, 17.9. 2009. The holotype is deposited in PRC (Hic designatus).

Taxonomy: Closterium pseudocostatum at first glance resembles C. costatum RaLfs. Corresponding characters are especially the coarsely costate cell wall [although the rib-like striae are usually not so much pronounced as in typical C. costatum and in some populations cells with a denser striation, similar to $C$. costatum var. borgei (WILLI KRIEG.) RŮŽIČKA, may occur (see e.g. Figs. 2, 3, 25 and 27)] and the distinctive cowl-shaped apex. However, there are also some remarkable differences in comparison with $C$. costatum, namely the somewhat less regular and rather weak curvature and particularly the presence of true girdle bands in all cells of the populations presently studied. True girdle bands differ from false or pseudo girdle bands in that they are formed more orderly: they develop following a vegetative cell division as a straight extension of the youngest semicell. In full-grown cells there is only one per semicell, each of approximately the same length (LÜTKEMÜLLER 1902). Pseudo girdle bands, on the contrary, vary in place, length and number, and may even be slightly curved. Not all Closterium species do form girdle bands, and there is a striking and fundamental difference in the way of cell-division in Closterium species with or without true girdle bands (RŮŽIČKA 1977). In the original description of $C$. costatum (RALFS 1848 , p. 170 , tab. 29 , fig. 1) no mention is made of any girdle bands at all. However, in later desmid monographs (e.g. RŮžIČKA 1977; FöRSTER 1982; Coesel \& Meesters 2007) the occasional presence of pseudo girdle bands was reported; most remarkably, KRIEGER (1937) even ranks $C$. costatum among the girdle band species!

Forms very similar to the present material have been reported from Arctic Norway by SCHARF (1981, Fig. 15) and from Austria by LeNZENWEGER (1996, pl. 6:2), both as C. costatum. Other findings probably representing $C$. pseudocostatum come from France (Deflandre 1927, fig. 3) and from south Germany (FörSTER 1964, tab. 2, figs 7-8), both labeled as $C$. costatum var. westii. Moreover, Brook \& Williamson (2010) present a semicell of a form with a (true?) girdle band that they consider similar to var. westii. This variety has been described by CuSHMAN (1905) referring to figures of W. \& G.S. West (1896, pl. 13: 23-24) from North America, showing two cells of an unnamed forma of $C$. costatum that are only faintly curved, have truncate apices and clear pseudo girdle bands, which are not mentioned in the text. Later, Cushman (1908, pl. 3: 14) provided an additional, somewhat poor and atypical figure of his new variety. Next, also from North America, a much more characteristic figure of a form of C. costatum with a pseudo girdle band is presented as var. westii by Borge (1909). Referring to Borge (l.c.), GRÖNBLAD (1920) reported C. costatum var. westii from central Finland, but presented a figure of a cell with a rather long, straight girdle band. However, a constant character of the forms mentioned above is that they only measure $230-300 \times 24-32 \mu \mathrm{m}$. Later, the concept of var. westii has been further confused by KRIEGER (1937; compare RŮžIČKA 1977 ) and therefore, we consider this variety very doubtful.

The last record of a form possibly representing C. pseudocostatum, is reported by JoHN \& Williamson $(2009$, p. 32, P1. 4A) from the west of Ireland. They labeled their specimen as 

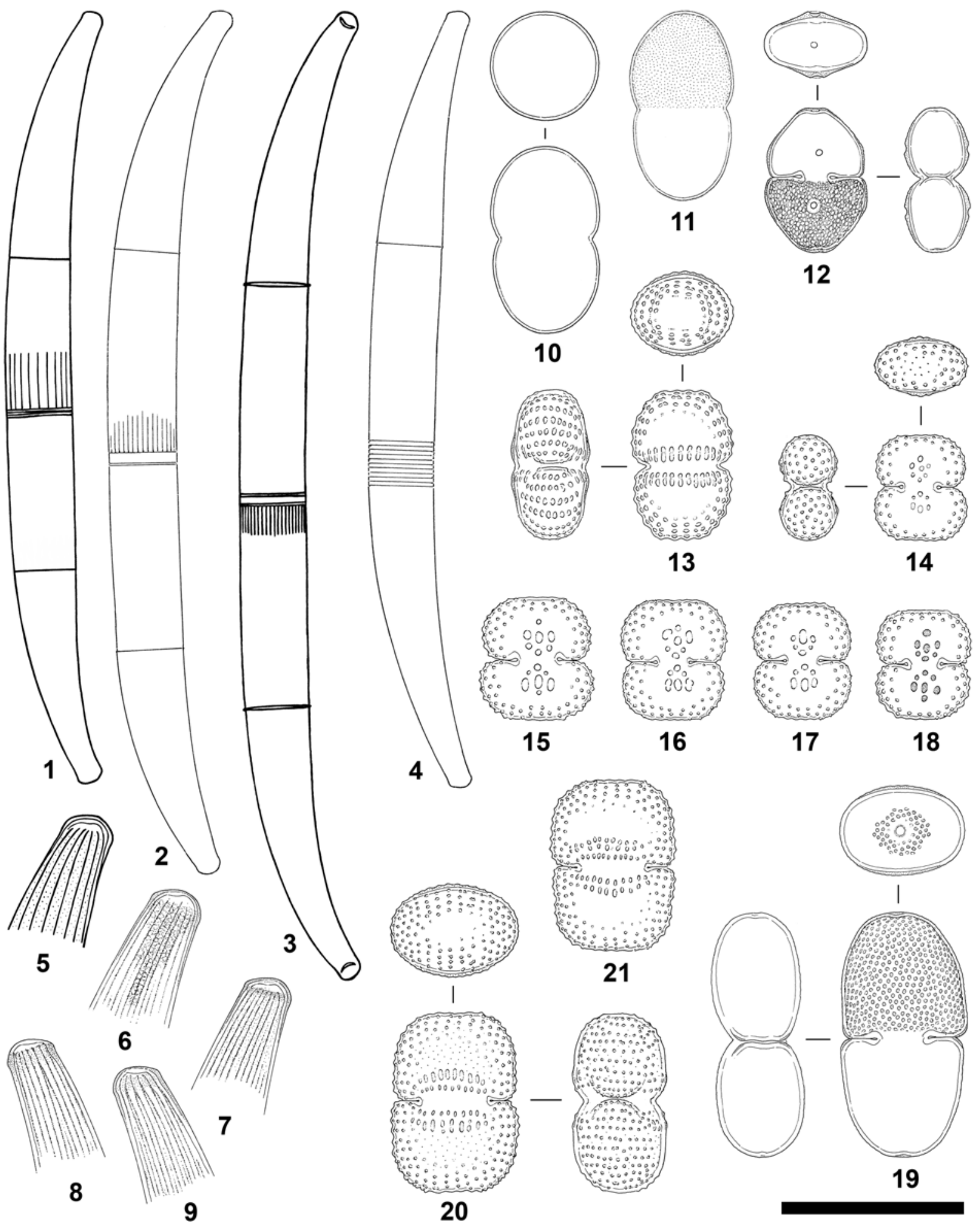

12

13
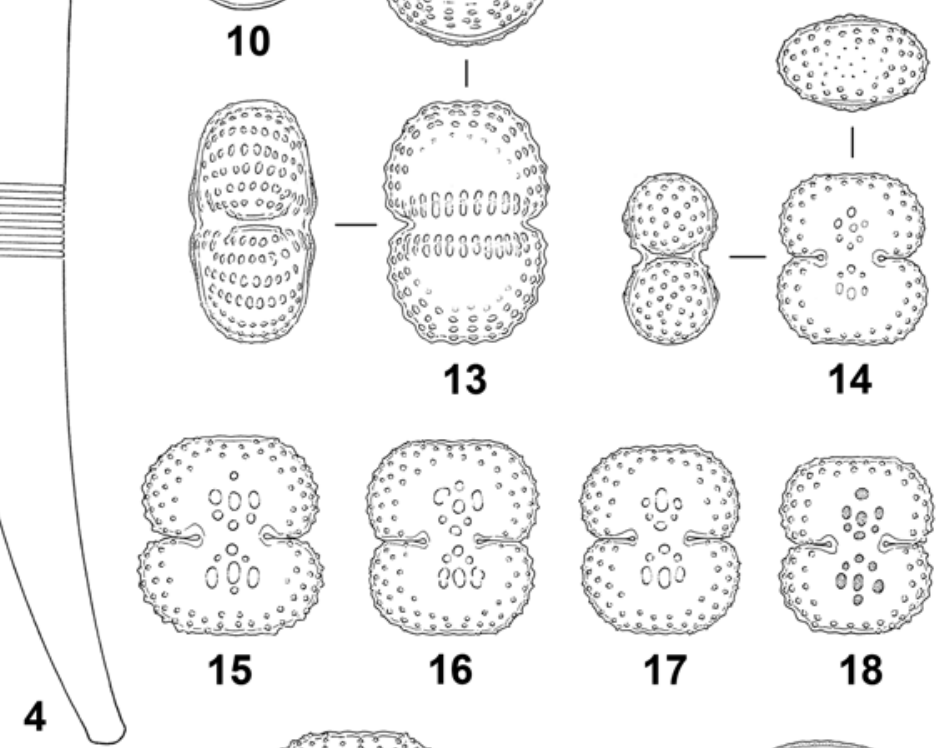

15

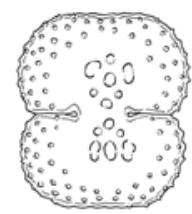

16
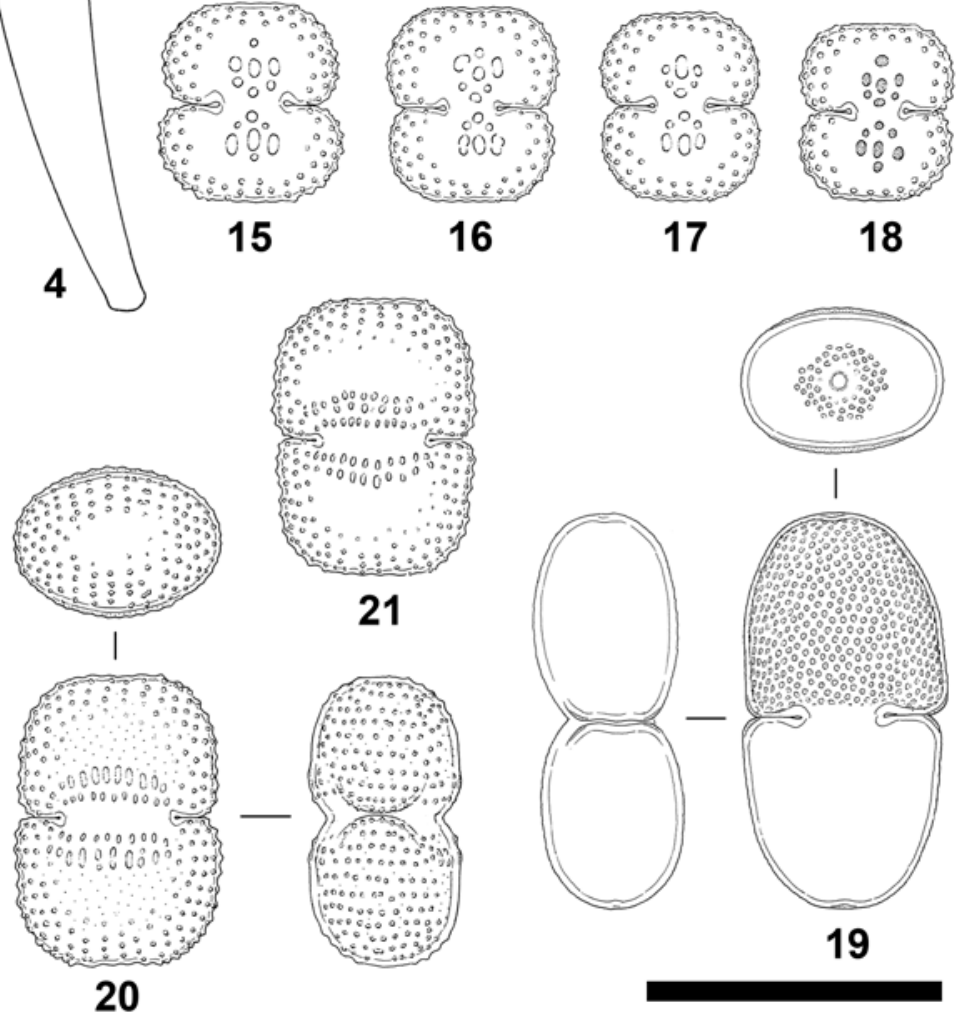

Figs 1-21. (1-9) Closterium pseudocostatum, (1-3) typically developed mature cells with two girdle bands and a various striation density, (4) young daughter cell with only one girdle band, (5-9) details of apices; (10-11) Actinotaenium riethii; (12) Cosmarium cataractarum; (13) C. cinctutum; (14-18) C. discrepans; (19) C. hostensiense; (20-21) C. lenzenwegeri. Scale bar $100 \mu \mathrm{m}$ (Figs 1-4), $50 \mu \mathrm{m}$ (Figs 5-21). 
C. costatum var. erectum GRÖNBLAD. This variety has been described by KRIEGER (1937) after a drawing sent to him by GRÖNBLAD that represented a cell with a straight middle part and measured $350 \times 42 \mu \mathrm{m}$. Unfortunately, KRIEGER (l.c.) did not reproduce this figure, no mention is made of girdle bands and this variety is also considered very doubtful.

On the basis of the observations mentioned above, we consider the description of Closterium pseudocostatum as a new species as fully justified since raising one of the doubtful varieties mentioned to species level seems not appropriate. Unfortunately, no details are available on the molecular background of the formation of girdle bands, and on the phylogenetic relation between the groups with and without these structures. It seems therefore a matter of speculation whether the present form has evolved from a typical $C$. costatum, or rather has evolved in parallel and independently, including the mutual morphological features (the coarsely costate cell wall and the typical cowl-shaped apex).

Cells of C. pseudocostatum with a denser striation are somewhat similar to $C$. intermedium RALFS, whose cells, however, are narrower and on average also shorter (approximately 200-400 $\times 20-30 \mu \mathrm{m})$ and lack the characteristic cowlshaped apex.

Ecology and distribution: Closterium pseudocostatum prefers mesotrophic, slightly acidic habitats and judging from the nature of its Czech (Břehyně-Pecopala NR, Swamp NR) and Austrian (the very desmid-rich "Schwemm" near Walchsee peat bog, see LENZENWEGER 2000; ŠŤASTNÝ \& LENZENWEGER 2008) sampling sites, its occurence seems to be limited to well-preserved biotopes with a high desmid diversity.

\section{Actinotaenium riethii Š ̌̌̃STNÝ et KouwETs sp. nov. (Figs 10-11, 28-30)}

Descriptio: cellulae cylindricae, a fronte visae late ellipticae, circiter $13 / 4$ longiores quam latae, in medio parum constrictae, apicibus late rotundatis, a vertice visae circulares, membrana subtilissime poribus ornata. Cellularum longitudo 39-54 $\mu \mathrm{m}$, latitudo 25 $31 \mu \mathrm{m}$, long./lat. circiter 1.55-1.95.

Description: cells approximately cylindrical with a slight median constriction, sinus very shallow and widely open. Apices broadly rounded, lacking any apical indentation or a distinct pore. Chloroplast stelloid, with 10-11 longitudinal ridges (4-5 visible in frontal view). Apical view circular. Cell wall densely set with fine pores.

Dimensions: length 39-54 $\mu \mathrm{m}$, breadth $25-31 \mu \mathrm{m}$, length/breadth ratio approximately $1.55-1.95$.

Type locality: site 4 (see Table 1), leg. J. Št'astný, 18.4. 2007. The holotype is deposited in PRC (Hic designatus).

Etymology: the new species is described in honour of Prof. Alfred Rieth who conducted an extensive study into diverse aspects of the biology of the form in question and presented arguments in favour of their description as a separate species.

Taxonomy: the Actinotaenium in question has been found on a number of periodically desiccating sites in the Czech Republic (the type locality and others) and could not be identified with any species described so far. The only paper reporting forms being probably identical with the newly described species is that by RIETH (1985). He described many aspects of the morphology and biology of two Actinotaenium forms he had found in a habitat very similar to the Czech sites ("von Regenwasser gespeisten, temporären Wegerandpfützen"). One of these taxa ("Form I" in RIETH l.c.) is obviously identical with our material. RIETH (l.c.) provisionally identified his material as A. curtum (Ralfs) Teiling var. globosum Wille, originally described as Penium curtum BRÉBISSON var. globosum by WiLLE (1879, tab. 13, fig. 72) from the Novaja Zemlja archipelago. However, at once he presented numerous arguments for raising this variety to the rank of species. Although the description presented by WILLE (l.c.) is rather poor and confusing (no apical view, no chloroplast details), our material as well as that described by RIETH (1985) obviously represent a taxon different from A. curtum var. globosum. As dimensions Wille (1879) gave 31-38 $\times 24-28 \mu \mathrm{m}$, whereas RIETH's $(39-54 \times 25-31 \mu \mathrm{m})$ as well as our specimens $(41.5-51.5 \times 26-29 \mu \mathrm{m})$ were much larger. The species in question has also nothing to do with the nominate variety of $A$. curtum, as the observations of RIETH (1985, under "Form II") convincingly demonstrate. A. curtum clearly differs by distinctly fusiform, comparatively narrower cells with an apical indentation bearing a distinct pore, and by cell wall that is much less densely set with pores than in $A$. riethii (ŠŤASTNÝ, pers. observation). Therefore, in our opinion the description of $A$. riethii as a new species is fully justified.

Ecology and distribution: Actinotaenium riethii is well characterized by its striking ecology. It is typical for periodically desiccating, usually 


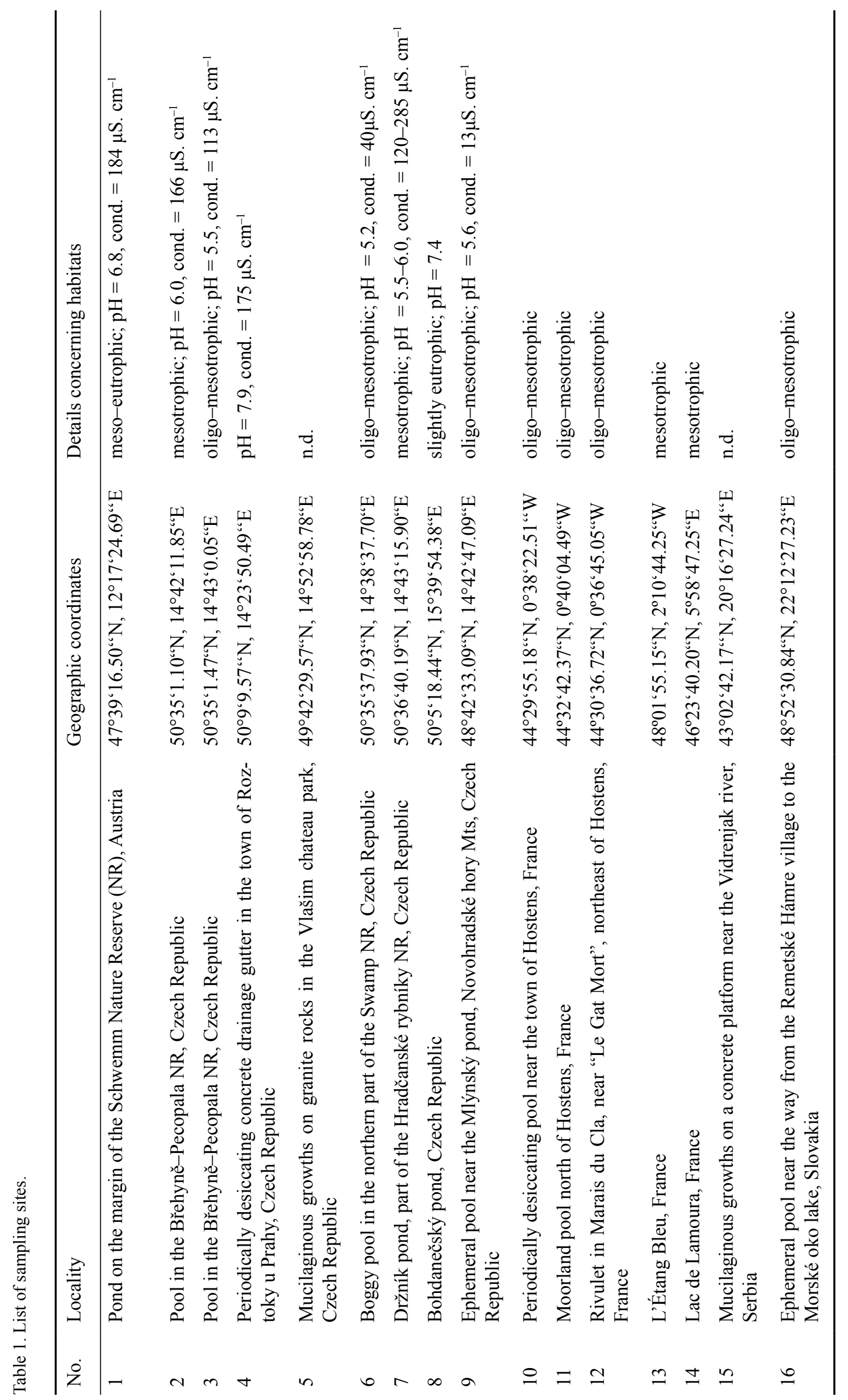


man-made substrata like, e.g., concrete drainage gutters, concrete platforms, etc. where it may cooccur in particular with A. curtum, Cosmarium pericymatium var. pericymaticum and var. corrugatum and Staurastrum habeebense, a drought-resistant desmid community typical for this type of habitats (ŠŤASTNÝ 2008). Here, it can be easily confused with $C$. pericymatium whose cells, however, are not omniradiate and therefore have different frontal and lateral views (compare, e.g., Williamson 2000, tab. 2, fig. 7). Most likely also the reports of A. cucurbita by BROOK (2001, found together with $C$. pericymatium and $S$. habeebense) from a sun-dial and by WILLIAMSON (2002, in a community with $C$. pericymatium var. pericymatium and var. corrugatum, S. habeebense and $A$. curtum) from a stone birdbath actually represent $A$. riethii.

\section{Cosmarium cataractarum (RACIBORSKI) EICHLER 1895 (Figs 12, 33-37)}

Basionym: Cosmarium variolatum LUNDELL var. cataractarum RACIBORSKI [1889, pl. 5(1), fig. 3]

Morphology and taxonomy: the cells are longer than broad with a deep, linear and closed sinus. Semicells are in outline pyramidal with rounded angles, straight to slightly convex sides and a slightly concave apex. In apical and lateral view they are elliptical, in apical view a slight median inflation is present. Cell wall coarsely scrobiculated and with a large scrobicula in the semicell centre.

Dimensions: length $37-42 \mu \mathrm{m}$, breadth $26-29$ $\mu \mathrm{m}$, thickness $17-19 \mu \mathrm{m}$, isthmus 7.5-9 $\mu \mathrm{m}$; length/breadth ratio approximately $1.30-1.40$.

Cosmarium cataractarum, found in sample from sites 7, 8 and 14, had originally been described as $C$. variolatum var. cataractarum by RACIBORSKI (1889, pl. 5, fig. 3) from southern Poland. RACIBORSKI (l.c.) obviously related his new form with $C$. variolatum LUNDELL on the basis of the similarity of the cell wall sculpture. The nominate variety of $C$. variolatum is also characterized by a coarsely scrobiculated cell wall and, according to the original description, var. cataractarum should only differ in the presence of a large scrobicula in the centre of each semicell (which, however, may rarely be reduced or even lacking; see Figs 36-37).

Under the light microscope the cell wall sculpture of both taxa indeed appears roughly the same (compare figs 264-5 and 266 in Š̆̌TASTNÝ
2010 or figs. 2 and 3 on pl. 49 in LENZENWEGER 1999). However, the use of SEM revealed remarkable differences. In C. variolatum, the cell wall sculpture consists of equally large and evenly distributed scrobiculae, each of them bearing a distinct pore (see Figs 31-32 after material from site 3 ). On the other hand, in var. cataractarum, the scrobiculae are generally more shallow, unevenly large (the larger being usually situated in the apical and lateral parts of the semicells), more densely distributed over the cell wall and the pores are located between them (see Figs 33-37). Generally, the cell wall sculpture in C. variolatum var. cataractarum more resembles that in $C$. pseudovariolatum GrönBLAD (see Couté \& TelL 1981, pl. 14, figs 3-6) than that in C. variolatum.

In addition, the ecological demands of the nominate variety of $C$. variolatum and var. cataractarum are quite different. The nominate variety is a rare species of mesotrophic, slightly acidic bogs, while var. cataractarum is a characteristic form from the tychoplankton of greater, meso- to slightly eutrophic and neutral to slightly alkaline water bodies (see e.g. ŠŤASTNÝ 2010).

Despite all the above-mentioned morphological and ecological differences, in desmidiological literature C. cataractarum is still generally considered a variety of $C$. variolatum. Only Eichler (1895) treated it as a separate species, but his view has not been generally accepted. However, our observations fully support EICHLER's (l.c.) opinion and confirm the status of C. cataractarum as a separate species.

\section{Cosmarium cinctutum NoRdsTEDT 1875 (Figs 13, 42-49)}

Morphology and taxonomy: the cells in our material, coming from site 5, are longer than broad with a very shallow, open sinus. Semicells are in outline trapeziform with convex lateral sides and undulate-crenate margins. In both apical and lateral view they are elliptical. Cell wall ornamentation is composed of radiating series of intramarginal and marginal, flat granulae and in addition of a horizontal band of 8-12 (mostly 10) elongate, irregular verrucae just above the isthmus (Figs 13, 42-47). The cells are 36-45 $\mu \mathrm{m}$ long, 25-29 $\mu \mathrm{m}$ wide and $20-23 \mu \mathrm{m}$ thick. The isthmus is $18.5-21.5 \mu \mathrm{m}$ wide. The length/width ratio is approximately $1.40-1.55$.

Our material showed some similarities with C. basiornatum (GRÖNBLAD) COESEL. This species 

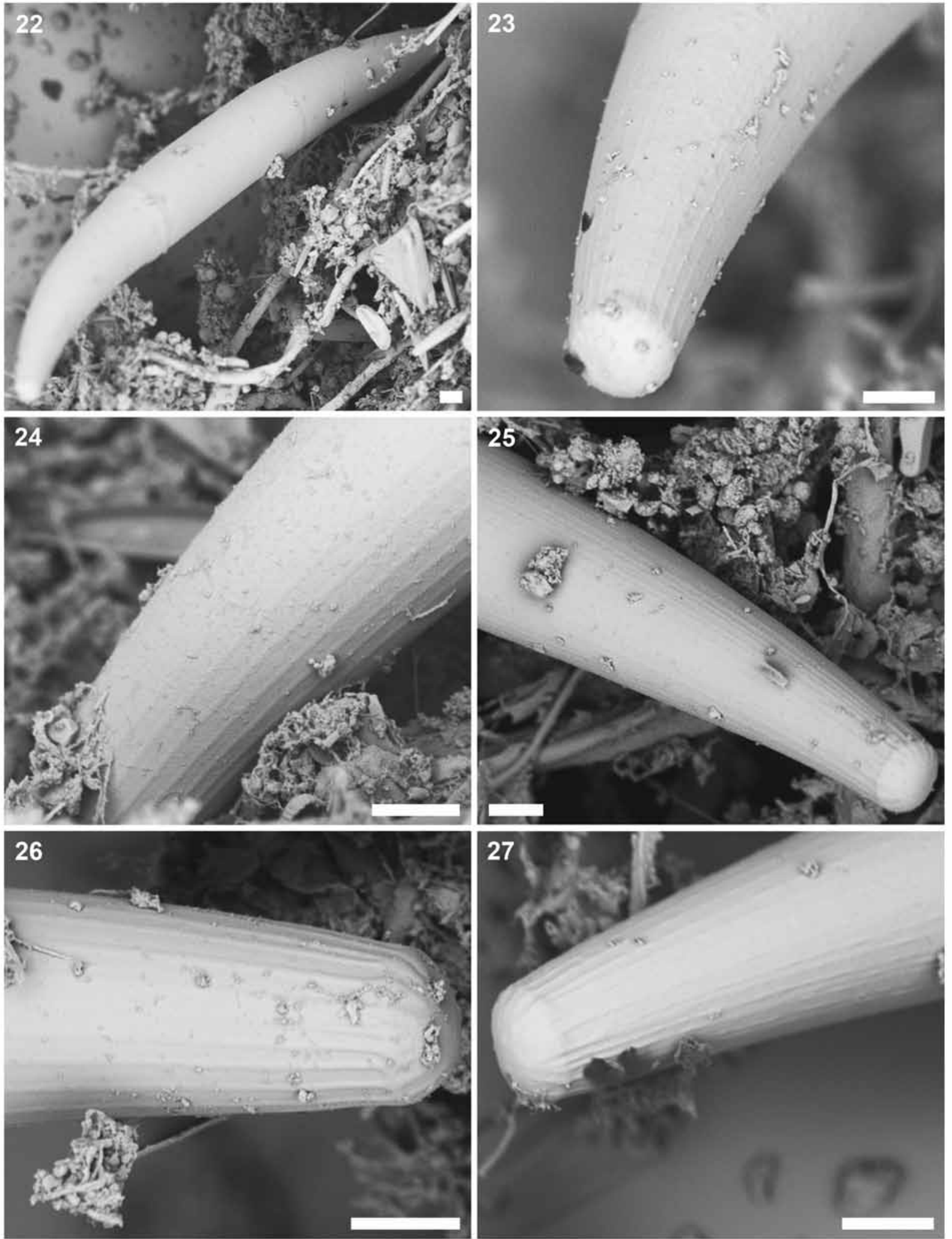

Figs 22-27. Closterium pseudocostatum: (22) whole cell, (23) detail of the same cell, (24-25) parts of cells with a less dense (24) and more dense (25) striation, (26-27) details of apices. Scale bar $10 \mu \mathrm{m}$. 

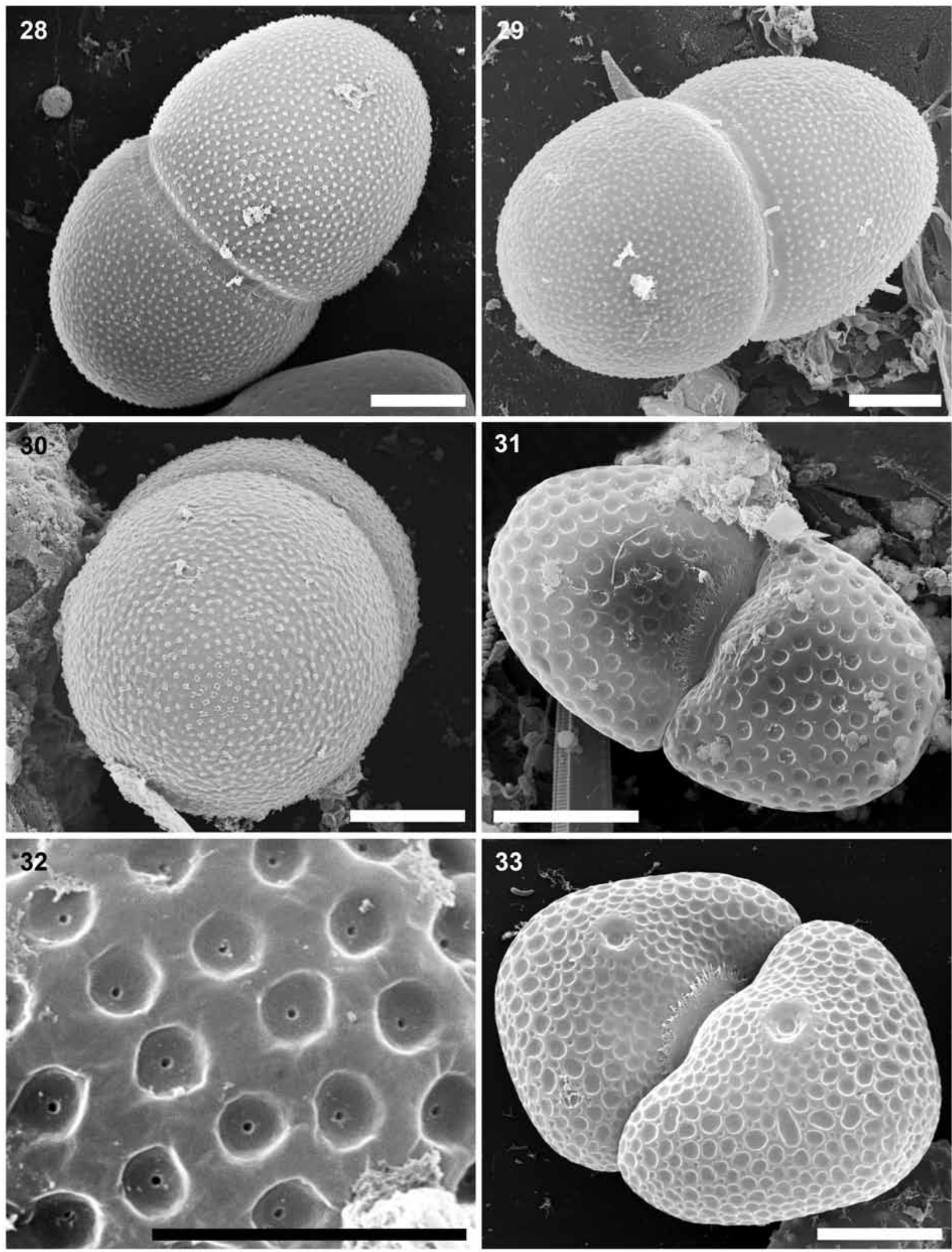

Figs 28-33. (28-30) Actinotaenium riethii, (30) apical view; (31-32) Cosmarium variolatum, (32) detail of cell wall sculpture; (33) C. cataractarum. Scale bar $10 \mu \mathrm{m}, 5 \mu \mathrm{m}$ (Fig. 32). 
was originally described by GRÖNBLAD (1926) as a variety of $C$. davidsonii J. Roy \& BISSET and rightly made a separate species by COESEL (1998). However, a closer look revealed several subtle differences between C. basiornatum and our specimen. C. basiornatum is characterized by truncate-pyramidate semicells with straight or only faintly convex sides, a very moderate, largely closed sinus, and an ornamentation of short, radiating series of comparatively large granules leaving the semicell centre smooth. In addition a supra-isthmial ornamentation of 6-8 longitudinal series of mostly two (seldom fusing) elongate warts is present. Also between this horizontal band and the radiating series near the basis a smooth zone is present (see Figs 38-39 after material from site 9; compare also Coesel 1998, pl. 11: 39-40; ŠŤASTNÝ 2010, figs 116-117). Dimensions are $37-41.5 \times 27-31 \mu \mathrm{m}$; isthmus $15-17 \mu \mathrm{m}$. The length/width ratio is approximately $1.28-1.37$.

Our material, on the other hand, has slightly more rounded semicells, an even more shallow, gaping sinus, and a different supraisthmial ornamentation that merges with the radiating series of granules near the basis. Finally, it has a higher length/breadth ratio. These characters rather match the diagnosis of $C$. cinctutum, given by NoRDSTEDT (1875). Unfortunately, NoRDSTEDT only presented the figures of two semicells, one agreeing with our material, one significantly broader which possibly is an artifact (NORDSTEDT l.c. pl. 7: 20a and 20a', respectively). As dimensions he gave $40 \times 28-33$ $\mu \mathrm{m}$, the larger width agreeing with his broader form.

Most remarkably, despite the above mentioned differences Coesel \& MeEsters (2007) without argumentation consider $C$. basiornatum a synonym of $C$. cinctutum, which name accordingly would have priority. However, in our opinion, both species should be kept apart.

C. cinctutum should also be compared with a few other species. C. tumens NorDSTEDT clearly differs by its characteristic supraisthmial ornamentation composed of 3-4 transversal rows of small granulae (Figs 40-41). In addition it has somewhat greater dimensions (in the Serbian population from site 15 cell dimensions were: length 43-52 $\mu \mathrm{m}$, width $30-35 \mu \mathrm{m}$, thickness 24.5-26.5 $\mu \mathrm{m}$, isthmus width $19-21 \mu \mathrm{m}$ ).

A second rather similar form is $C$. speciosum var. rostafinskii (GuTwiŃsKI) W. et G.S. West, originally described as $C$. rostafinskii ["Rostafińskii”] by GutwiŃski (1890; see also
GUTwiŃSKI 1892). However, general morphology and ornamentation of this form shows more affinity with C. basiornatum (compare also SkUJA 1928). Croasdale (1962) described the slightly smaller C. cinctutum var. reductum, but this variety does not seem very closely related although the figures are somewhat confusing (CROASDALE l.c. pl. 5: 80-82). Finally, RACIBORSKI (1889) reported a form of $C$. cinctutum from a locality near Dresden, unfortunately without figures, measuring 36-47 $\times$ 26-30 $\mu \mathrm{m}$, thickness $21-22 \mu \mathrm{m}$ and isthmus $21-$ $25 \mu \mathrm{m}$.

Ecology and distribution: as far as could be traced, up till now only one other more or less reliable record of $C$. cinctutum has been published. KossinskaJA (1936) mentioned the species presenting a detailed drawing after material collected near the Gulf of Jenisej, in Arctic Russia (KossinsKaJA l.c. pl. 3: 6). However, her-single - figure seems slightly different from the present material concerning the shape of the isthmus and the development of the lateral crenations. The dimensions of her material are near the lower end of the range given above. C. cinctutum apparently is a rare, predominantly Arctic-Alpine species, presumably preferring hemi-atmophytic habitats.

Cosmarium discrepans Š Š ̌STNÝ et Kouwets sp. nov. (Figs 14-18, 52-57)

Descriptio: cellulae subparvae, paullo longiores quam latae, medio sinu anguste lineato profunde constrictae; semicellulae subtrapezi- subreniformes, angulis basalibus late rotundatis, superioribus obtusorotundatis, dorso truncatae, a vertice visae ellipticae, a latere visae subrotundatae; membrana intra margine granulis seribus irregulariter dispositis ornatis, supra isthmum granulo paullo majore ornatae, apicem versus granulis 2 minoris, granulis verruciformis plerumque geminatis 3, interdum granulo singulo ornatae. Cellularum longitudo 29-34 $\mu \mathrm{m}$, latitudo 24-29 $\mu \mathrm{m}$, crassitudo 16.5-18.5 $\mu \mathrm{m}$, long./lat. circiter 1.10-1.25.

Description: the cells are slightly longer than broad, with a deep, linear and closed sinus. The semicells are approximately oval in outline with rounded basal angles and convex lateral sides that rather merge with the truncate apex. The cell wall ornamentation is composed of radiating series of small intramarginal/marginal granulae and a characteristic central ornamentation, consisting of a uniquely arranged rosette of wart-like granules. Between central and marginal ornamentation a smooth zone is present. The central ornamentation is rather variable, generally showing a prominent 
supraisthmial granule with, more apically, on either side a somewhat smaller granule. Above this a more or less horizontal series of three elongate warts is situated. These warts, and particularly the central one, show a strong tendency to subdivide, so that the total number of granulae may vary between six and nine and usually comprises seven. The variability of the central sculpture is particularly well visible in Figs 52-57. The apical view is ellipsoid with a slight median inflation, the lateral view is (sub)circular (see Fig. 14). Dimensions: length 29-34 $\mu \mathrm{m}$, breadth $24-29$ $\mu \mathrm{m}$, thickness $16.5-18.5 \mu \mathrm{m}$, isthmus $9-11 \mu \mathrm{m}$; length/breadth ratio approximately 1.10-1.25.

Type locality: site 6 (see Table 1), leg. J. Št'astný, 22.9. 2006. The holotype is deposited in PRC (Hic designatus).

Etymology: the epith "discrepans" means "different" pointing to the fact that this new species obviously has been considered a form of C. punctulatum.

Taxonomy: Cosmarium discrepans rather closely resembles $C$. punctulatum BRÉB. var. subpunctulatum (Nordst.) Børgesen, originally described as $C$. subpunctulatum by NoRDSTEDT (1887, p. 160) from New Zealand. Searching the literature several reports of this taxon were found that are almost certainly identical with $C$. discrepans. Compare in particular the forms in COMPÈRE (1980, fig. 48) from the Belgian part of the Ardennes highlands, in Williamson (1992, figs 19,4$)$ from the Shetland Islands and also the interesting find of Williamson (2004, pl. 3 , fig. 7) from the Indonesian Island Sulawesi. Most probably also the findings of W. \& G.S. West (1897, pl. 6, fig. 19, as C. subpunctulatum NordstedT) from South England and DuboIsTYLSKI (1969, pl. 1, fig. 20) from the French part of the Ardennes highlands represent the taxon in question.

The above-mentioned records are generally specified to originate from acidic and oligotrophic environments. On the other hand, C. punctulatum var. subpunctulatum is a common species of mesoeutrophic, slightly acidic to slightly alkaline waters (e.g. Coesel \& Meesters 2007, ŠŤastný 2010). In addition to this striking difference in ecology of both taxa there is also a difference in cell wall ornamentation. The granulae in C. punctulatum var. subpunctulatum are generally somewhat more delicate than those in $C$. discrepans and in particular the central ornamentation of the semicells is very different. In C. punctulatum var. subpunctulatum this central ornamentation is composed of a horizontal row of 4 or 5 , rather small supraisthmial granulae with more apically a group of 6-9, variably arranged and sometimes geminate granulae (compare NORDSTEDT 1888, pl. 5, fig. 8, see also Figs 50-51 after material from site 1).

Ecology and distribution: Cosmarium discrepans was found by the first author in several localities in northern Bohemia (the type locality and some others) and northern Belgium (De Teut NR). The second author encountered it almost simultaneously on several sites in the west of France (Bretagne, Aquitaine, sites 11, 12, 13). All sampling sites were generally acidic and oligo(-meso)trophic and the species in question often occurred in high numbers. Most likely it is a rather rare, but widely distributed species of oligomesotrophic, acidic, well preserved habitats.

\section{Cosmarium hostensiense ŠŤASTNÝ et Kouwets} sp. nov. (Figs 19, 58-61)

Descriptio: cellulae a fronte visae ellipticae, profunde constrictae, sinu anguste lineari, apicibus subtruncatis-rotundatis in medio insectis, a vertice visae late ovatae, a latera visae compresse ovatae; membrana scrobiculata, scrobiculis poris ornatis. Cellularum longitudo 53-67 $\mu \mathrm{m}$, latitudo 30-35 $\mu \mathrm{m}$, crassitudo 23-25 $\mu \mathrm{m}$, long./lat. circiter 1.75-2.00

Description: cells in outline truncately elliptic, about twice as long as broad, deeply constricted; basal angles rather acutely rounded, sides convex, straight to occasionally slightly concave and gradually tapering towards the truncately rounded apex. Cell wall evenly and densely covered with marked scrobiculae. Dimensions: length 53-67 $\mu \mathrm{m}$, breadth 30-35 $\mu \mathrm{m}$, thickness $23-25$ $\mu \mathrm{m}$, isthmus $12.5-14 \mu \mathrm{m}$; length/breadth ratio approximately $1.75-2.00$.

Type locality: site 10 (see Table 1), leg. J. Št'astný, 12.3. 2009. The holotype is deposited in PRC (Hic designatus).

Etymology: the new species is named after Hostens, the French district where the type locality is situated.

Taxonomy: in a sample from locality 10, the first author found yet another desmid that is generally associated with C. variolatum, i.e. a form currently known as $C$. variolatum var. skujae.

This rather conspicuous variety had originally been described by CROASDALE in Croasdale \& Flint (1988, p. 112, pl. 36, fig. 13), after a figure published by SkuJA (1976) 

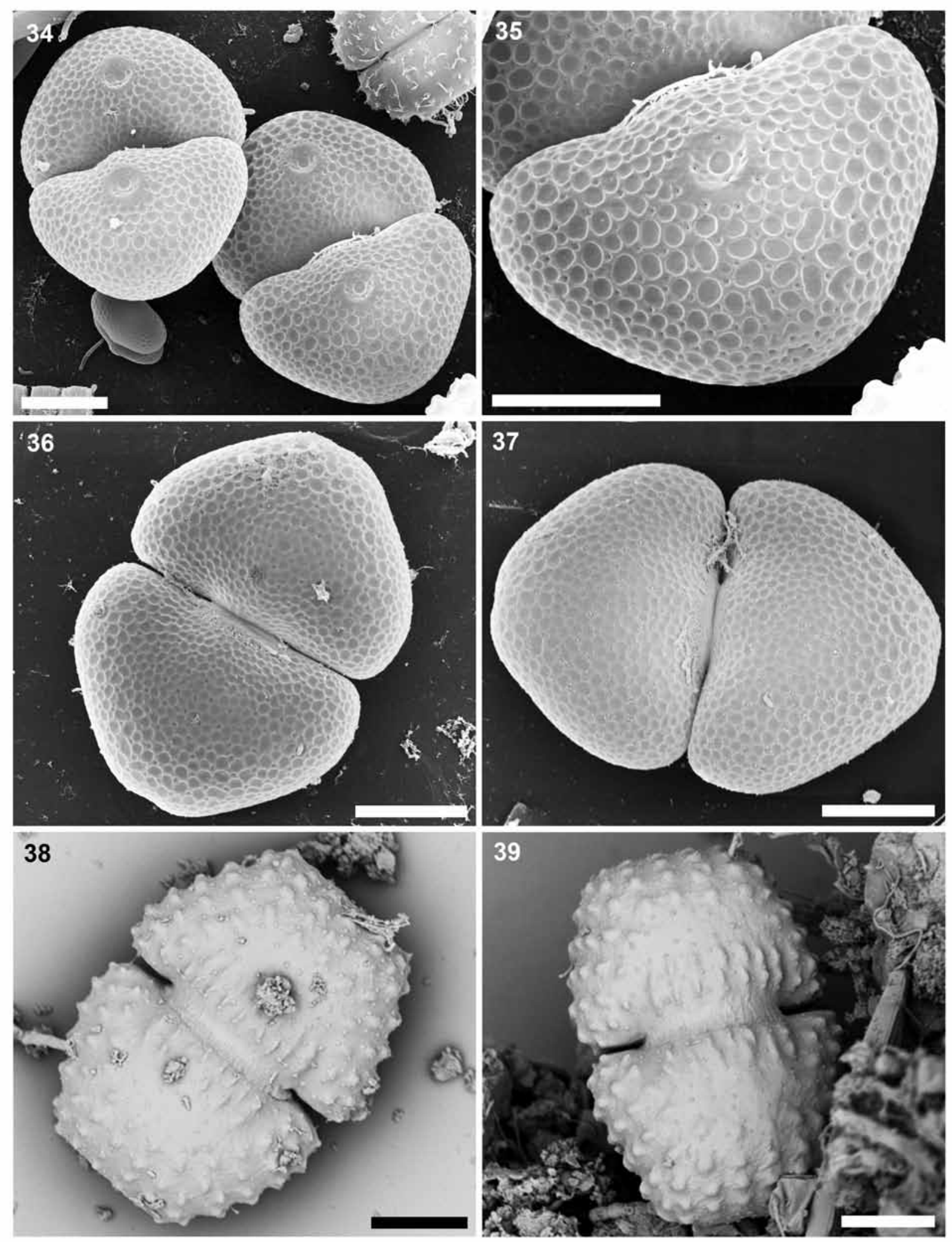

Figs 34-39. (34-37) Cosmarium cataractarum, (34) typically developed cells, (35) detail of cell wall sculpture, (36-37) anomalous cells with very weakly developed (upper semicell in 36) or completely lacking central scrobiculae; (38-39) $C$. basiornatum. Scale bar $10 \mu \mathrm{m}$. 

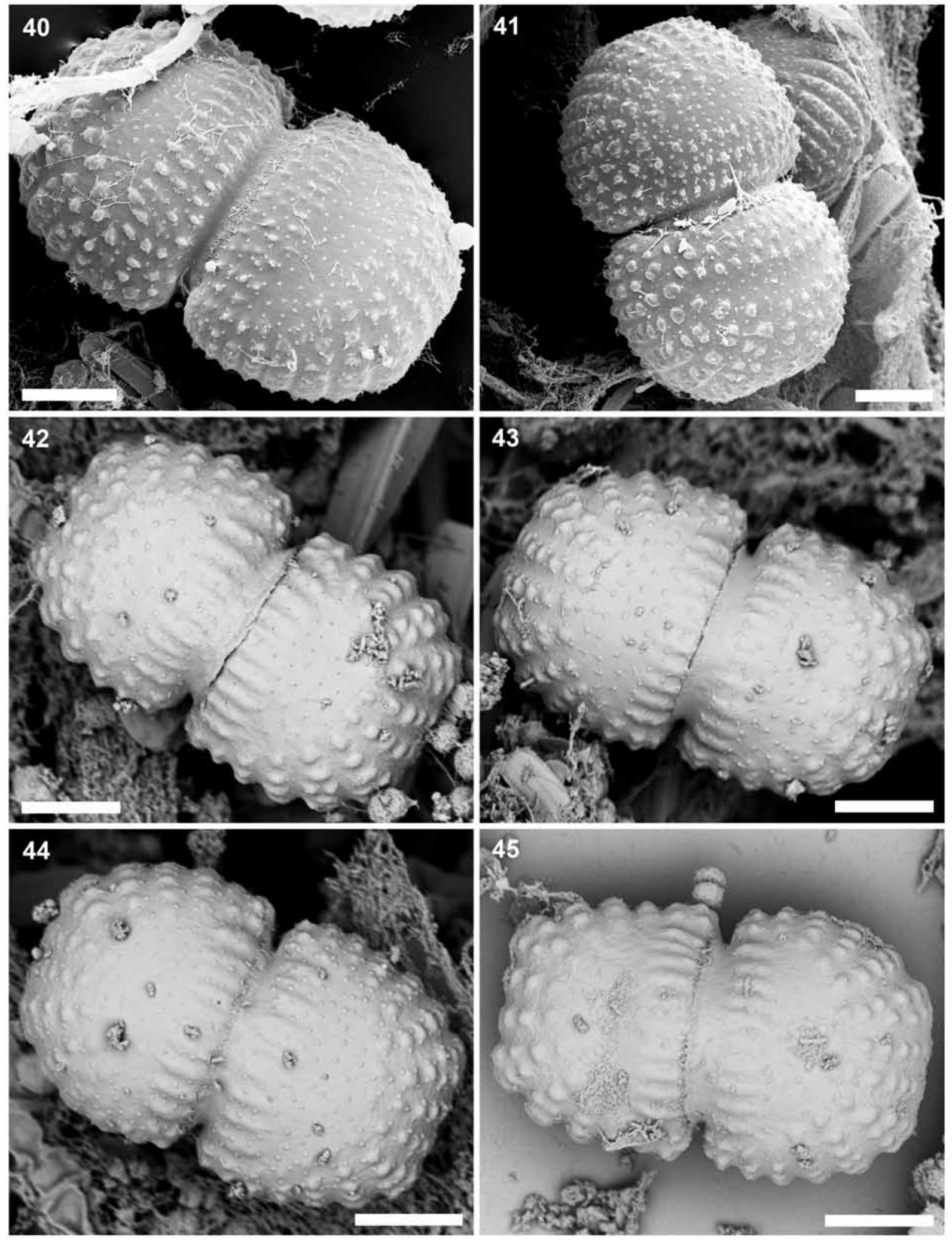

Figs 40-45. (40-41) Cosmarium tumens; (42-45) C. cinctutum. Scale bar $10 \mu \mathrm{m}$ 

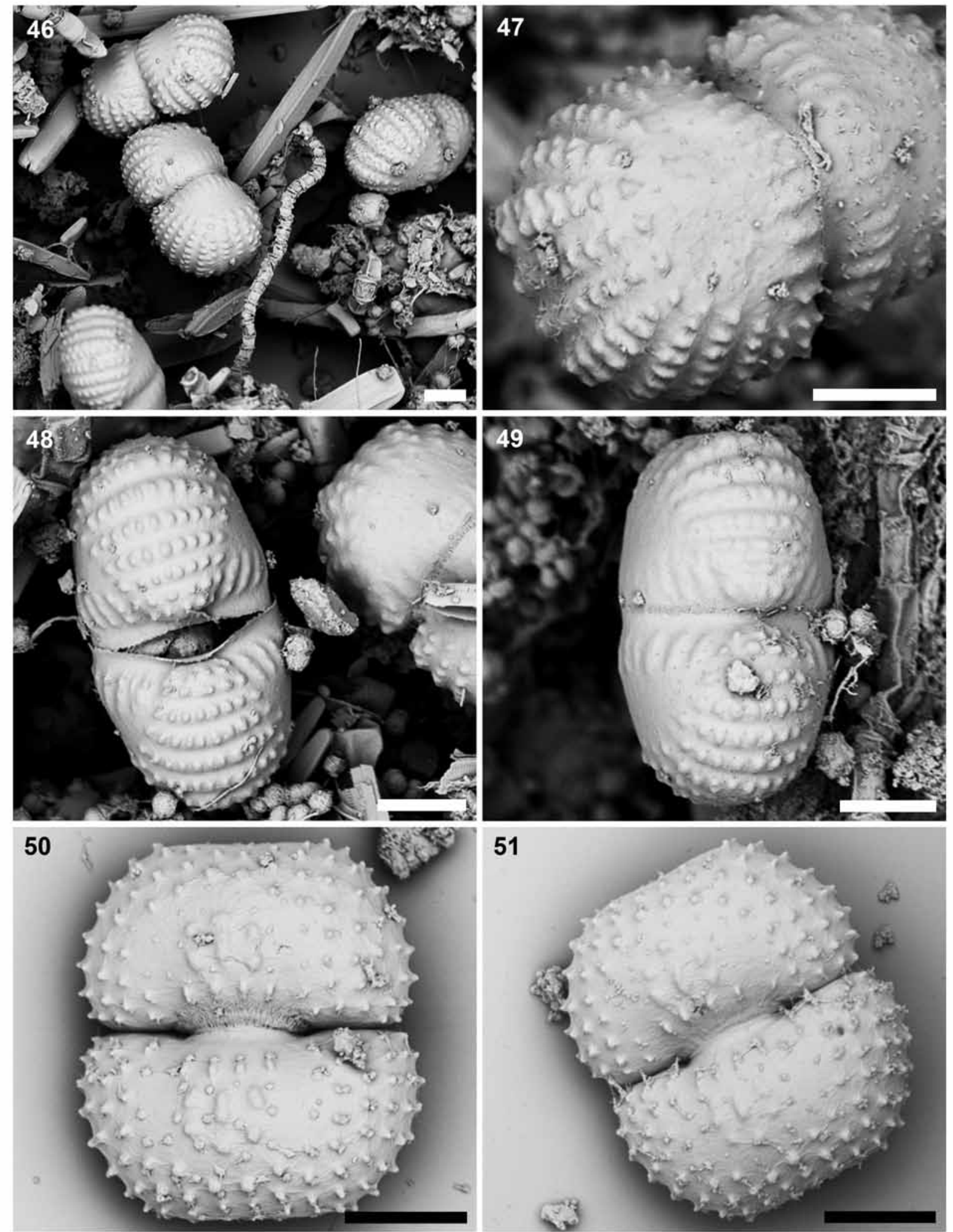

Figs 46-51. (46-49) Cosmarium cinctutum, (47) detail of the apical part of a cell, (48-49) lateral view; (50-51) C. punctulatum var. subpunctulatum. Scale bar $10 \mu \mathrm{m}$. 


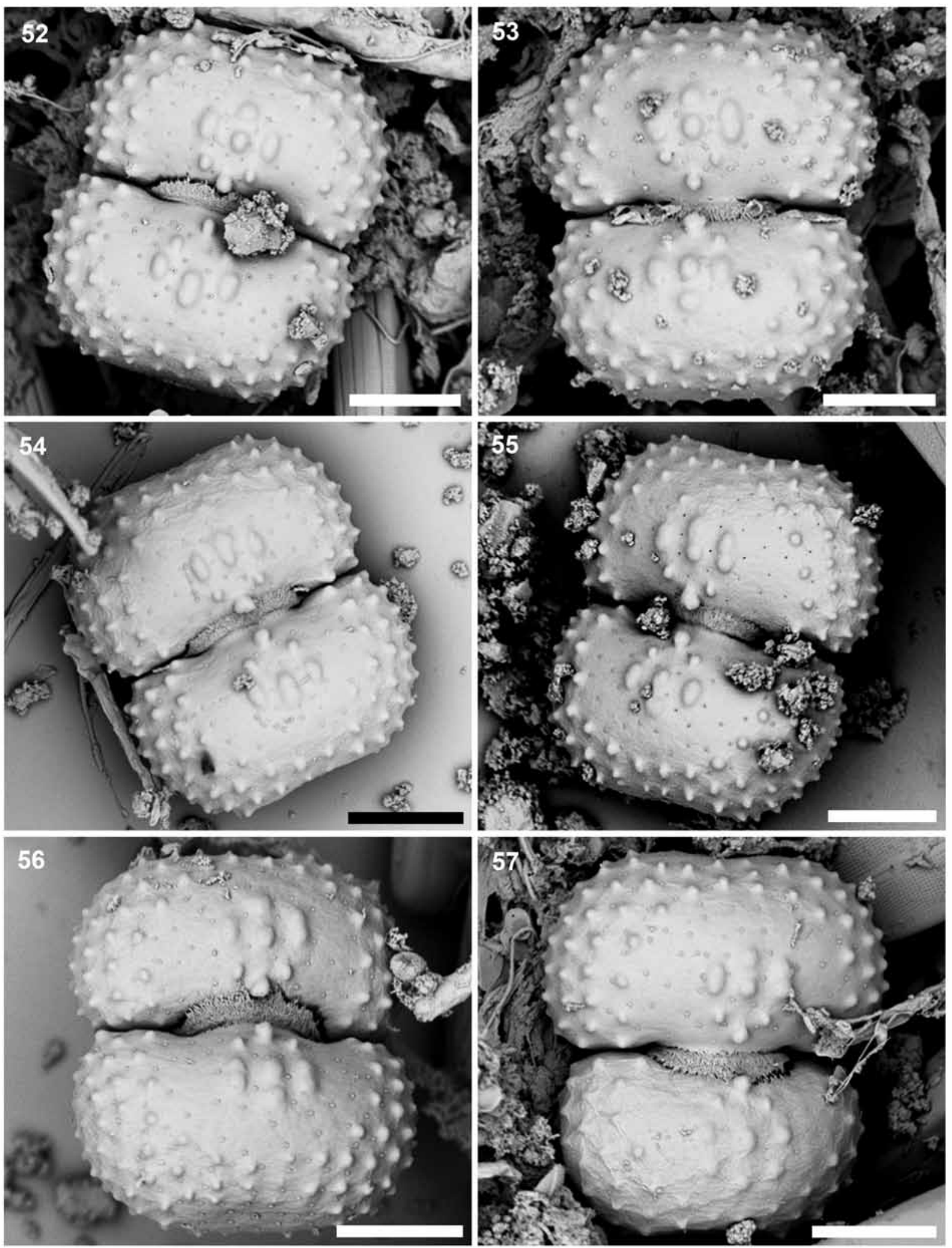

Figs 52-57. (52-57) Cosmarium discrepans. Scale bar $10 \mu \mathrm{m}$. 

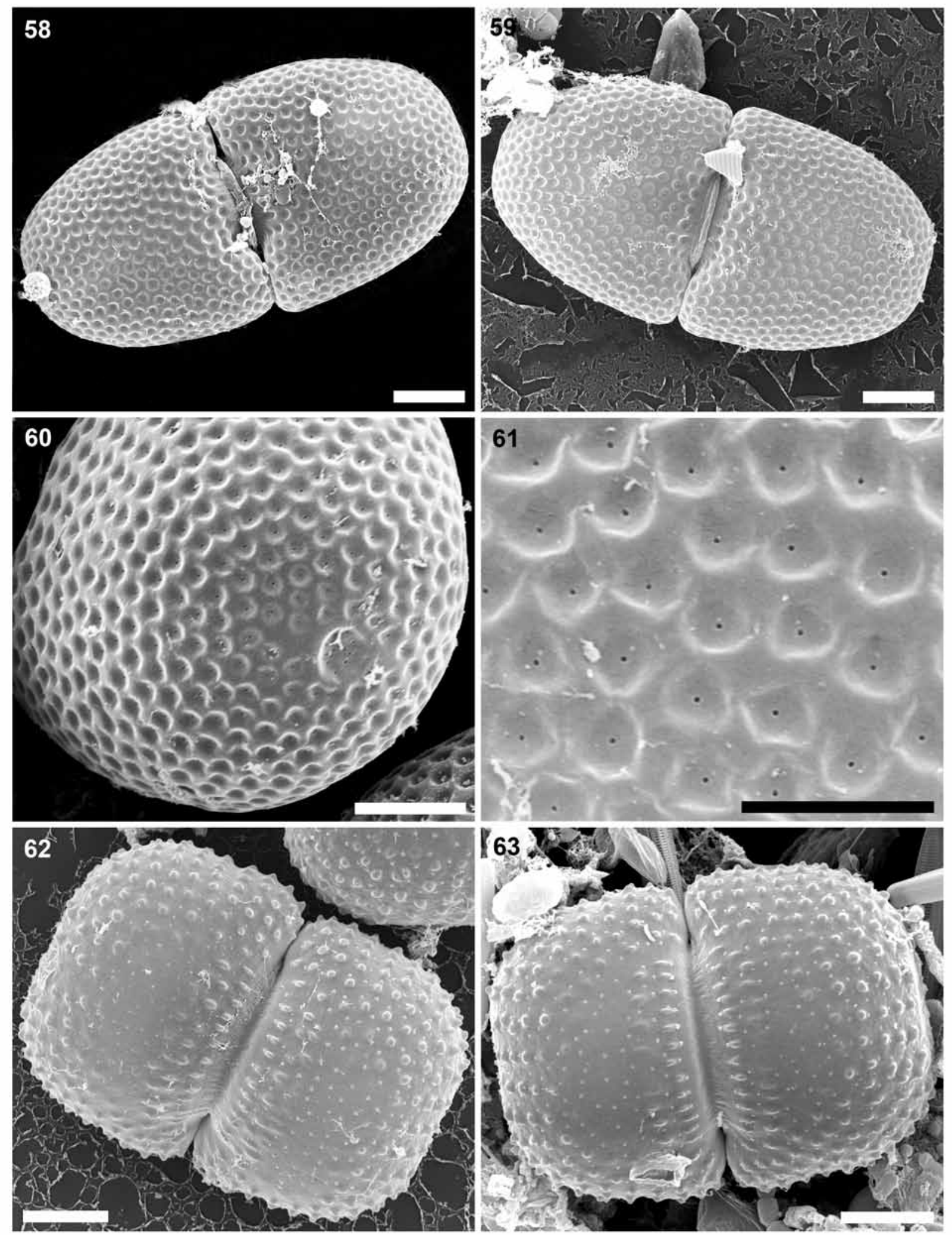

Figs 58-63. (58-61) Cosmarium hostensiense, (60) detail of the apical part of a semicell, (61) detail of cell wall sculpture; (62-63) C. lenzenwegeri. Scale bar $10 \mu \mathrm{m}, 5 \mu \mathrm{m}$ (Fig. 61). 

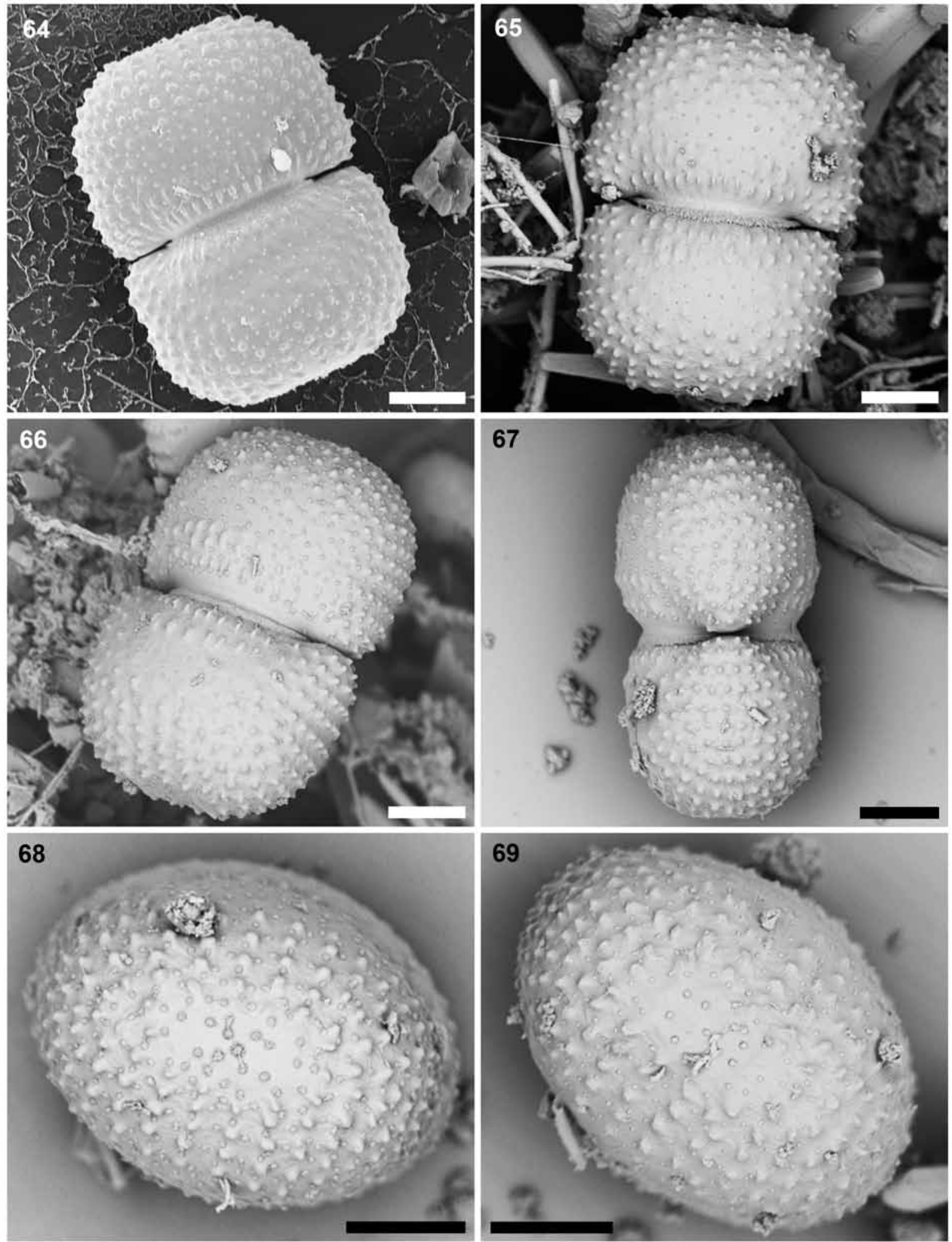

Figs 64-69. (64-69) Cosmarium lenzenwegeri, (67) lateral view, (68-69) apical views. Scale bar $10 \mu \mathrm{m}$. 
under $C$. variolatum var. extensum NoRDSTEDT (SkUJA l.c., P1. 9, Figs. 6-7). Last mentioned variety had previously been transferred to $C$. pseudopyramidatum P. LUNDELL by KRIEGER \& GerLofF (1965, p. 127), apparently on the basis of similarities in general cell wall sculpture and morphology (compare NoRDSTEDT 1887, p. 161, 1888, p. 55, pl. 6:3a). However, SKUJA's form obviously is not related to NORDSTEDT's var. extensum, inducing CROASDALE to retain it in C. variolatum, giving it the new varietal name skujae. By doing so, she in fact described it as a new taxon, unfortunately without providing a Latin diagnosis and indicating a type, so that her description is invalid according to ICBN Articles 36.2 and 37.1 (MCNeILl et al. 2006).

Thepresentmaterialprovided theopportunity to study this taxon with SEM, in order to reveal its cell wall sculpture and clarify its systematic position. Contrary to C. cataractarum, the cell wall of the present form has a pattern very similar to the nominate variety of $C$. variolatum, consisting of rather coarse scrobiculae with a central pore (see Fig. 61). However, in our opinion the general cell morphology - including dimensions - of the present form is too much different from that of $C$. variolatum to merely consider it a variety of the latter (compare also KouwETs 2008). Moreover, as with $C$. cataractarum there is a striking difference in the ecology between both taxa and, therefore, it is proposed to classify it as a separate species. Since a $C$. skujae has already been described by Krieger \& Gerloff (1965), a new name must be chosen, and we propose the name Cosmarium hostensiense.

Ecology and distribution: Cosmarium hostensiense obviously prefers acidic, more or less oligotrophic, often periodically desiccating water bodies. For instance in the west of Ireland it is one of the most common and often dominant desmids in this type of habitats (Š ̌̌ASTNÝ, personal observations; see also JoHN \& WILLIAMSON 2009).

\section{Cosmarium lenzenwegeri ŠřASTNÝ et KOUWETS} nom. nov. et stat. nov. (Figs 20-21, 62-69)

Synonym: Cosmarium subbroomei SCHMidLE var. taylorii CROASDALE (1956, pl. 16, figs 12-13)

Etymology: the new name of the present form is given in honour of Prof. Rupert Lenzenweger who conducted extensive investigations into desmids of higher altitudes, particularly in the Austrian Alps.
Morphology and taxonomy: the cells are distinctly longer than broad, in frontal view rather oblong-rectangular with a relatively shallow, linear, closed sinus and broadly rounded apical angles (Figs 20-21, 62-65). The semicells are somewhat subrectangular with rounded basal angles and parallel to slightly convergent, straight to slightly concave sides and a straight apex. In apical view they are elliptical; in lateral view subelliptic. The cell wall ornamentation is composed of radiating series of small granules running across the sides and by 2-3 transversal rows of elongate granules just above the isthmus (Figs 20-21, 62-66). The cells are 45-52.5 $\mu \mathrm{m}$ long, 33-37.5 $\mu \mathrm{m}$ wide and 24-26 $\mu \mathrm{m}$ thick. The isthmus is $16.5-20 \mu \mathrm{m}$ wide. The length/width ratio is approximately $1.3-1.4$.

The present, conspicuous, but unfamiliar Cosmarium form has been found in great abundance in an ephemeral pool in eastern Slovakia (site 16). Scrutinizing the literature for figures of this form only the report of Cosmarium subbroomei ScHMIDLE var. taylorii ["Taylorii"], described by CROASDALE (1956) from Alaska, came into consideration for the identification. This variety is morphologically almost identical with our material, differing basically only in its slightly greater dimensions, measuring 57-58 × 47-48 $\mu \mathrm{m}$. Moreover, although CROASDAle (l.c.) does not mention any explicit details about the habitat her variety was found ("On stones, branches, etc., in brooks and rivers"), some of the accompanying species (e.g. Cosmarium holmiense var. integrum, C. pokornyanum, C. speciosum var. simplex) point to a (hemi-)atmophytic habitat type, similar to our sampling site. A superficially related form seems to be $C$. diplodesmium, described from northern Sweden by SKUJA (1964, p. 214, pl. 36, fig. 20), but this form is slightly smaller and more coarsely granulated.

However, in our opinion CroASDALE's (l.c.) form has no relationship with $C$. subbroomei SchmidLE. Moreover, C. subbroomei is generally considered a very dubious taxon. When examining SCHMIDLE's original figures of this species (Schmide 1893, pl. 5, figs 22-24), it seems obvious that he included two markedly different taxa, one represented by Fig. 22, the other by Figs. 23-24. In their "British Desmidiaceae", W. \& G.S. WeST (1912, pl. 100, fig. 10) only gave a copy of ScHMidLE's fig. 22, at the same time stating that they had never seen a form exactly like it (W. \& G.S. West l.c., p. 24). Therefore, to 
preclude any taxonomic confusion, we propose to raise $C$. subbroomei var. taylorii to the rank of a separate species. Since a Cosmarium taylorii has already been described by CARTER [1935, as "Taylori", synonym Actinotaenium taylorii (CARTER) Teiling], a new name has to be choosen as to avoid the creation of a later homonym.

Ecology and distribution: Cosmarium lenzenwegeri obviously is a very rare (hemi-) atmophytic species, most probably with an arcticalpine distribution.

\section{Conclusions}

The present study confirms the usefulness of SEM revealed morphological cell wall characteristics for the description and delimitation of desmid species. Although molecular research suggests a much more complicated taxonomy (e.g. GonTCHAROV \& MelKonian 2008, 2011), cell morphology still is an important character for routine identification and SEM apparently is a welcome additional tool. This has also been concluded by other authors (e.g. Coesel 1984; Gontcharov et al. 2002; Neustupa et al. 2010) and its full potential obviously hasn't been realized yet. This especially concerns smaller forms with few morphological characteristics where it may be used for the delimitation of (pseudo)cryptic species. As already stressed by COESEL (1984) differences in cell wall sculpturing should be of equal importance in the identification of taxa as, e.g., differences in form and arrangement of cell wall ornamentation such as granules or spines. The significance of cell wall sculpture for the taxonomy of desmids should be further investigated.

The present results also draw attention to the actual biodiversity question, trying to assess the overall global number of desmid taxa. On one hand they illustrate the often desultory description of infraspecific desmid taxa by many authors (Cosmarium variolatum var. cataractarum, $C$. subbroomei var. taylorii; compare KouwETs 2008), paying no attention to conspicuous distinctive morphological characters. On the other hand they show that in cases where a description of a new species would be fully justified (Closterium pseudocostatum, Cosmarium discrepans) such distinctive characters are frequently overlooked or simply ignored and obviously considered to be part of the variability of the species in question.

It is clear that the cases discussed in the present paper only represent the "tip of the iceberg" and that many of the infraspecific desmid taxa described so far should be better considered separate species. This trend has been convincingly demonstrated in several recent papers (e.g. Neustupa et al. 2010, 2011; Nemjová et al. 2011). In our opinion, it can be assumed that the estimation of the overall global desmid species number by Hoshaw et al. (1990, 15000 spp.) is much more realistic than for instance that by CRANWELl et al. (1990, 1500 spp.) and probably much higher than the recent number of desmid taxa described (ca. 4000; GERRATH 1993).

Finally, the present results also demonstrate that ephemeral pools, where several taxa discussed above have been found, certainly still include a number of little known or undescribed desmid species and should not be ignored in investigations of desmid diversity.

\section{Acknowledgements}

The study was supported by grant 206/09/0906 of Czech Science Foundation and by Charles University Science Foundation B BIO 432311/2011 grant.

\section{References}

Borge, O.(1909): NordamerikanischeSüsswasseralgen. - Arkiv för Botanik 8, N:o 13: 1-29.

Brook, A.J. (1981): The biology of desmids. - 276 pp., Botanical Monographs Vol. 16. Blackwell Scientific Publications, Oxford, London, Edinburgh, Boston, Melbourne.

Brook, A.J. (2001): The drought resistant desmid, Cosmarium pericymatium Nordstedt, and a description of the new var. corrugatum. Quekett Journal of Microscopy 39: 127-132.

Brook, A. \& Williamson, D. (2010): A monograph on some British desmids. - 364 pp., The Ray Society, London.

Carter, N. (1935): Alpine desmids from British Columbia. - Linnean Society Journal of Botany 50: 151-174.

Coesel, P.F.M. (1984): Taxonomic implications of SEM revealed cell wall sculpturing in some small-sized desmid species (Chlorophyta, Conjugatophyceae). $\quad$ - Acta Botanica Neerlandica 33: 385-398.

Coesel, P.F.M. (1998): Sieralgen en Natuurwaarden. 56 pp., Stichting Uitgeverij KNNV Utrecht.

Coesel, P.F.M. \& Meesters, J. (2007): Desmids of the Lowlands. Mesotaeniaceae and Desmidiaceae of the European Lowlands. - 351 pp., KNNV Publishing, Zeist, The Netherlands. 
Compère, P. (1980): Quelques algues de la région de Brûly (France, Dépt. Des Ardennes; Belgique, Prov. de Namur). - Bulletin de la Société royale de botanique de Belgique 112: 151-165.

Couté, A. \& Tell, G. (1981): Ultrastructure de la paroi cellulaire des Desmidiacées au microscope électronique à balayage. - Beihefte zur Nova Hedwigia 68: 1-228.

Cranwell, P.A.G.; Jaworski, H. \& Bickley, H.M. (1990): Hydrocarbons, sterols, esters and fatty acids in six freshwater chlorophytes. Phytochemistry 29: 145-151.

Croasdale, H.T. (1956): Freshwater algae of Alaska. I. Some desmids from the interior. Part 2: Actinotaenium, Micrasterias and Cosmarium. - Transactions of the American Microscopical Society 75: 1-70.

Croasdale, H. (1962): Freshwater algae of Alaska III. Desmids from the Cape Thompson Area. - Transactions of the American Microscopical Society 81: $12-42$.

Croasdale, H.T. \& Flint, E.A. (1988): Flora of New Zealand. Freshwater algae, Chlorophyta, desmids. - 147 pp., Botany division, D.S.I.R., Christchurch, New Zealand.

Cushman, J.A. (1905): A contribution to the desmid flora of New Hampshire. - Rhodora 7: 101119; 251-266.

Cushman, J.A. (1908): New England species of Closterium. - Bulletin of the Torrey Botanical Club 35: 109-134.

Deflandre, G. (1927): Contributions à la flore algologique de France - I. Confolentais. Bulletin de la Société Botanique de France 73(1926): 987-999.

Dubois-TyLski, T. (1969): Florule algologique d'un marais d'Ardenne. - Revue Algologique II, 9: 316-325.

EICHLER, B. (1895): Materyały do flory wodorostów okolicMiedzyrzeca.-PamietnikFizyjograficzny 14: 53-63.

FÖRSTER, K. (1964): Beitrag zur Desmidiaceenflora des Ost-Allgäus. - Berichte der Bayerischen Botanischen Gesselschaft 37: 41-52.

FÖrSTER, K. (1982): Conjugatophyceae-Zygnematales und Desmidiales (excl. Zygnemataceae). - In: Huber-Pestalozzi, G. (eds.): Das Phytoplankton des Süsswassers, 8. Teil, 1. Hälfte. - 291 pp., E. Schweizerbart'sche Verlagsbuchhandlung, Stuttgart.

GerRath, J.F. (1993): The biology of desmids: a decade of progress. - Progress in phycological research 9: 79-192.

Gontcharov (2008): Phylogeny and classification of Zygnematophyceae (Streptophyta): current state of affairs. - Fottea 8: 87-104.

Gontcharov, A.A.; Finlay, D.L.; Kling, H.J. \& Watanabe, M.M.(2002): Desmids(Desmidiales,
Streptophyta)from the Experimental Lakes Area, Ontario, Canada. The genera Actinotaenium and Cosmarium. - Algological Studies 106: 17-41.

Gontcharov, A.A.; Marin, B. \& Melkonian, M. (2003): Molecular phylogeny of conjugating green algae (Zygnemophyceae, Streptophyta) inferred from SSU rDNA sequence comparisons. - J. Mol. Evol. 56: 89-104.

Gontcharov, A.A. \& Melkonian, M. (2005): Molecular phylogeny of Staurastrum Meyen ex Ralfs and related genera (Zygnematophyceae, Streptophyta) based on coding and noncoding rDNA sequence comparisons. - J. Phycol. 41: 887-899.

Gontcharov, A.A \& Melkonian, M. (2008): In search of monophyletic taxa in the family Desmidiaceae (Zygnematophyceae, Viridiplantae): the genus Cosmarium. Am. J. Bot. 95:1079-1095.

Gontcharov, A.A. \& Melkonian, M. (2010): Molecular phylogeny and revision of the genus Netrium (Zygnematophyceae, Streptophyta): Nucleotaenium gen. nov. - J. Phycol. 46: 346362.

Gontcharov, A.A. \& Melkonian, M. (2011): A study of conflict between molecular phylogeny and taxonomy in the Desmidiaceae (Streptophyta, Viridiplantae): Analyses of $291 \mathrm{rbcL}$ sequences. - Protist 162: 253-267.

GRÖNBlaD, R. (1920): Finnländische Desmidiaceen aus Keuru. - Acta Societatis pro Fauna et Flora Fennica 47: 1-98.

GRÖNBLAD (1926): Beitrag zur Kenntnis der DesmidiaceenSchlesiens.-Societas Scientiarum Fennica, Commentationes Biologicae 2: 1-39.

GuTwiŃSKI (1890): Zur Wahrung der Priorität. Botanisches Centralblatt 43: 65-73.

GUTwiŃSKI (1892): Flora glonów okolic Lwowa (Flora algarum agri Leopoliensis). - Sprawozdanie Komisyi Fizyograficznej Akademija Umiejetnosci W Krakowie, Czesc II 27 (1891): $1-124$.

Hall, J.D.; Karol, K.G.; McCourt, R.M. \& Delwiche, C.F. (2008): Phylogeny of the conjugating green algae based on chloroplast and mitochondrial nucleotide sequence data. - J. Phycol. 44: 467477.

Hoshaw, R.W.; McCourt, R.M. \& Wang, J.C. (1990): Phylum Conjugaphyta. - In: Margulis, L., Carliss, J. O. \& Melkonian, M. (eds): Handbook of Protoctista. - pp. 119-131, Jones and Bartlett, Boston, USA.

John, D.M. \& Williamson, D.B. (2009): A practical guide to the desmids of the West of Ireland. - 196 pp., Martin Ryan Institute, National University of Ireland, Galway.

KossinsKajA, E.K. (1936): Desmidievye vodorosli iz Artiki (Desmidien der Arktis; in Russian with German summary). - Trudy Botaniceskogo 
Instituta Akademii Nauk SSSR, Serija 2, Sporovye Rastenija 3: 401-449.

Kouwets, F.A.C. (2008): The species concepts in desmids: the problem of variability, infraspecific taxa and the monothetic species definition. Biologia 63: 877-883.

KrIEGER, W. (1937): Die Desmidiaceen Europas mit Berücksichtigung der aussereuropäischen Arten. - In: RABENHORST`s Kryptogamen-Flora von Deutschland, Österreich und der Schweiz 13, Abteilung 1, Teil 1. - 712 pp., Akademische Verlagsgesellschaft M.B.H., Leipzig.

Krieger, W. \& Gerloff, J. (1965): Die Gattung Cosmarium. Lieferung 2. - 128 pp., J. Cramer, Weinheim.

LENZENWEGER, R. (1996): Desmidiaceenflora von Österreich, Teil 1. - In: CRAMER, J. (ed.): Bibliotheca Phycologica 101. - 162 pp., Gebrüder Borntraeger Verlagsbuchhandlung, Berlin-Stuttgart.

LenZENWEgeR, R. (1999): Desmidiaceenflora von Österreich, Teil 3. - In: CrAMER, J. (ed.): Bibliotheca Phycologica 104. - 218 pp., Gebrüder Borntraeger Verlagsbuchhandlung, Berlin-Stuttgart.

LeNZENWEgeR, R. (2000): Vorläufiges Ergebnis der Untersuchungen zur Zieralgenflora der Schwemm bei Walchsee in Nordtirol (Desmidiaceae). $\quad-\quad$ Berichte des Naturwissenschaftlich-medizinischen Vereines in Innsbruck 87: 41-66.

LÜTKEMÜLLER (1902): Die Zellmembran der Desmidiaceen. - Cohn, Beiträge zur Biologie der Pflanzen 8: 347-414.

McCourt, R.M.; Karol, K.G.; Bell, J.; HelmBychowsKi, K.M.; GrajeWSKA, A.; Wojciechowski, M.F. \& Hoshaw, R.W. (2000): Phylogeny of the conjugating green algae (Zygnemophyceae) based on rbcL sequences. J. Phycol. 36: 747-758.

McNeill, J.; Barrie, F.R.; Burdet, H.M.; Demoulin, V.; Hawksworth, D.L.; Marhold, K.; Nicolson, D.H.; Prado, J.; Silva, P.C.; Skog, J.E.; Wiersema, J.H. \& Turland, N.J. (2006): International Code of Botanical Nomenclature (Vienna Code), Regn. Veg. 146. - 568 pp., A.R.G. Gantner Verlag KG, Ruggell.

Nemjová, K.; Neustupa, J.; ŠŤastný, J.; ŠKaloud, P. \& VeselÁ, J. (2011): Species concept and morphological differentiation of strains traditionally assigned to Micrasterias truncata. - Phycol. Res. 59: 208-220.

Neustupa, J. \& Š KKaloud, P. (2007): Geometric morphometrics and qualitative patterns in the morphological variation of five species of Micrasterias (Zygnemophyceae, Viridiplantae). - Preslia 79: 401-417.

Neustupa, J.; ŠKaloud, P. \& ŠŤastný, J. (2010):
The molecular phylogenetic and geometric morphometric evaluation of Micrasterias cruxmelitensis / M.radians species complex. - J. Phycol. 46: 703-714.

Neustupa, J.; ŠŤastný, J.; Nemjová, K.; Mazalová, P.; Goodyer, E.; PoulíčKová, A. \& ŠKaloud, P. (2011): A novel, combined approach to assessing species delimitation and biogeography within the well-known desmid species Micrasterias fimbriata and $M$. rotata (Desmidiales, Steptophyta). - Hydrobiologia 667: 223-239.

Nordstedt, C.F.O. (1875): Desmidieae arctoae. Öfversicht af Kongl.Vetenskaps-Akademiens Förhandligar 1875: 13-43.

NordstedT, C.F.O. (1887): Algologiska småsaker. 4. Utdrag ur ett arbete öfver de af Dr. S. Berggren på Nya Seland och i Australien samlade sötvatteralgerna. - Botaniska Notiser 1887: 153-164.

Nordstedt, C.F.O. (1888): Fresh-water algae collected by Dr. S. Berggren in New Zealand and Australia. - Kongliga Svenska VetenskapsAkademiens Handlingar 22: 1-98.

Raciborski, M. (1889): Desmidyje nowe. - Pamietnik Akademii Umiejetnosci w Krakowie, Wydzial Matematyczno-Przyrodniczy 17: 73-113.

RAlFs, J. (1848): British Desmidieae. - 226 pp., Reeve, Benham \& Reeve, London.

RIETH, A. (1985): Seltene oder bemerkenswerte Algen auf dem Gelände des Zentralinstituts für Genetik und Kulturpflanzenforschung Gatersleben. II.Actinotaenium TeILING, 1954. - Archiv für Protistenkunde 130: 53-77.

RŮŽıČKA, J. (1977): Die Desmidiaceen Mitteleuropas, Band 1, 1. Lieferung. - 291 pp., E. Schweizerbart'sche Verlagsbuchhandlung, Stuttgart.

Scharf, W. (1981): Zieralgen aus dem arktischen Norwegen. - Cryptogamie, Algologie 2: 3156.

Schmidle, W. (1893): Beiträge zur Algenflora des Schwarzwaldes und der Rheinebene. - Berichte der Naturforschenden Gesellschaft zu Freiburg i. Br. 7: 68-112.

SkuJA, H. (1928): Vorarbeiten zu einer Algenflora von Lettland. IV. - Acta Horti Botanici Universitatis Latviensis 3: 103-218 [Reprinted in Bibliotheca Phycologica Band 26 (1976): 121-240].

SkujA, H. (1964): Grundzüge der Algenflora und Algenvegetation der Fjeldgegenden um Abisko in Schwedisch-Lappland. - Nova Acta Regiae Societatis Scientiarum Upsaliensis, Ser. IV 18 (N:o 3): 1-465.

Skuja, H. (1976): Zur Kenntniss der Algen neuseeländischer Torfmoore. - Nova Acta Regiae Societatis Scientiarum Upsaliensis, V, 2: $1-158$.

ŠŤASTNÝ, J. (2008): Desmids from ephemeral pools and 
aerophytic habitats from the Czech Republic. Biologia 63: 884-890.

ŠŤASTNÝ, J. (2010): Desmids (Conjugatophyceae, Viridiplantae) from the Czech Republic; new and rare taxa, distribution, ecology. - Fottea 10: $1-74$.

ŠŤASTNÝ, J. \& LENZENWEGER R. (2008): Ein Nachtrag zur Zieralgenflora (Desmidiales, Zygnematophyceae) der Schwemm bei Walchsee in Nordtirol (Österreich). - Phyton (Horn, Austria) 48: 37-49.

West, W. \& West, G.S. (1896): On some North American Desmidieae. - Transactions of the Linnean Society of London, Ser. 2 Botany 5: 229-274.

West, W. \& West, G.S. (1897): A contribution to the freshwater algae of the south of England. Journal of the Royal Microscopical Society 17: 467-511.

West, W. \& West, G.S. (1912): A monograph of the British Desmidiaceae. Volume 4. - 194 pp., The Ray Society, London.
WiLle, N. (1879): Ferskvandsalger fra Novaja Semlja samlede af Dr. F. Kjellman paa Nordenskiölds Expedition 1875. - Öfversicht af Kongliga Vetenskaps-Akademiens Förhandlingar 1879: 13-74.

Williamson, D.B. (1992): A contribution to our knowledge of the desmids flora of the Shetland Islands. - Botanical Journal of Scotland 46: 233-285.

Williamson, D.B. (2000): Some desmid floras of wet rock surfaces. - Algological Studies 97: 11-27.

Williamson, D.B. (2002): Rare desmids from garden ornaments and Scottish lochs. - Algological Studies 105: 79-86.

Williamson, D.B. (2004): Some desmids from the Rawa Aopa National Park, south-east Sulawesi, Indonesia. - Algological Studies 114: 85-97.

Woloszynska, J. (1918): Przyczynek do znajomosci glonów Litwy. - Rozprawy Wydzialu Matematyczno-Przyrodniczego Polskiej Akademii Umiejetnosci, Serija III, Dzial B (Nauki Biologiczne) 17: 221-247.

(C) Czech Phycological Society (2012)

Received December 16, 2011

Accepted February 28, 2012 